\title{
Viewing Environmental Issues from Ecofeminism --- Ecofeminism Views in "The Story of One Hour"
}

\begin{abstract}
Jiamin Zhang
Beijing No.101 Middle School, Beijing100091, China

Email:Jiaminzhang01202003@outlook.com

ABSTRACT

Women and nature are same in various ways due to their biological status, reproductive role, and discrimination. Ecological feminism is an organic combination of feminist and ecological thoughts that has been present in various forms from the start of feminism in the nineteenth century, articulated through the work of women gardeners, botanists, animal welfare advocates, etc. Ecofeminism clearly reveals the oppressive structure in the relationship between man and nature, and between humans, enable us to establish a new type of equal relationship between man and nature and between man and man. Hence, ecofeminism is one of theoretical and practical way to resolve environmental problems. The famous female writer Kate Chopin presented audience with a sense of feminism and nature, and criticized patriarchal oppression of women through clever metaphors. People and nature should belong to a whole, which is a relationship of mutual harmony and coexistence. This paper uses the literature research method and the theory-to-practice method, starting from a short story, proposes the application of ecofeminism in literature, and explain the deep meaning of ecofeminism and its instruction role in environmental law. This study indicates the use of ecofeminism in literature work and showed that ecofeminism has instructional effect on the environmental law.
\end{abstract}

\section{Keywords: Ecofeminism, Environmental Science, Feminism, The Story of an Hour}

\section{INTRODUCTION}

Nature should be protected by modern people, especially under rapid urbanization process. Due to increasingly development of technology and unlimited needs of human beings, our environment is devastated and ruined severely, which attaches more importance on changing our paradigm in regard to our behavior toward nature that can reduce inevitable destruction of our common land in the future. However, it is not enough to analyze the devastation of the earth only in terms of human social and adoption of technology. There is a pressing need to centralize women's issues and to incorporate their collective perspectives, experiences and contributions to sustainable development.

Ecofeminism, based on gender perspective, is referred as an active component of the process of environmental protection. From ecofeminist, women and nature are roughly in the same position: they are both defined as passive subjects that subjected to violence and social inequalities. Ecofeminism is not environmental movement which is strictly feminine, but because the status of women and nature in the modern world are similar to some extent, people premise that ideology which authorizes oppressions based on race is the approximately same as the ideology which sanctions the oppression of nature. There are a large amount of literature works reflecting the love for nature as a woman by depicting the nature landscape to express female's desire for freedom. This paper shows that ecological feminism and ecology are complement and mutual subjects.

\subsection{Presumed Connections Between Women and Nature}

Similarities between ecofeminism and ecosystem ecology can be considered through the hierarchy theory. These similarities suggest that ecofeminism and ecosystem inform and support one another. The notion of patriarchal and oppressive conceptual framework is as central to ecofeminism and ecofeminist ethics as the notion of hierarchy theory in ecosystem ecology: one could not generate any complete and impartial conclusions of each without them.

There is a direct and natural connection between the oppression endured by women and the oppression of 
nature. The Creator passed on the ability of giving life from Mother Earth to women [1]. Nature and women play a similar role in the process of creation: women use their flesh and blood to give birth to children, and convert food into milk for feeding their offspring; the earth circulates and produces abundant products and provides a complex biosphere containing life. While people conceptualize female as the one to turn to and to give ceaselessly without expecting return, human beings also exploited the environment as if there were unlimited and free natural resources. The obvious connection between nature and women caused them to encounter the same fate under a specific cultural background. In ancient times, the power of divinity was strong, and nature and women are highly respected by society, but with the occurrence of the scientific revolution and the widespread use of science and technology, the sacredness of women and nature has gradually disappeared, and the lofty social status has also been subverted by the patriarchal system. The natural world is manipulated by human, losing initiative, and women also lose their important social status due to the decline of their natural status, and become the object of male rule. Technology developed in the Victorian period, and it has completely transformed nature and women into subjects for human (men) aggression and conquest. Spontaneously, nature and women are in an oppressive position in a patriarchal society, and the fate of the two are closely related and share the same honor and disgrace.

\subsection{Ecofeminisim and Its View of Ecology}

\subsubsection{Origin of ecofeminism}

Eco-feminism is a social trend of thought that converged with the vigorous development of contemporary western environmental movements and the rise of women's movements that actively adapts to the needs of social change. One of the roots of eco-feminism is environmentalism. Under the patriarchal system, women are usually required to work directly related to nature, such as raising poultry and livestock, obtaining salaries and handling food, etc., which makes women considered to be closer to nature. Historical development proves that women often enter environmental protection and ecological conservation-related industries and (none-governmental organizations) NGOs more often than men, but they find that men often occupy the most important position. This makes these women who have considerable knowledge, expertise, and sports experience in green thoughts, deep ecology, and animal liberation, beginning to think about the relationship between ecology and gender.

A series of ecological disasters in the 1970s caused some feminist protests. Women's active participation in the ecological protection movement gave a rise to the theory of ecological feminism. Ecofeminist historians most often given credit for its intellectual and theoretical spadework to a Frenchwoman writing in the early 1970s [2]. In 1974, French "feminist" scholar François first proposed the concept of ecological feminism in the book Feminism Destruction. She tried to appeal to female leaders an ecological movement, re-understanding and thinking about the relationship between human and nature.

\subsubsection{Characterization of ecofeminism}

Ecofeminism contains two major components, ecological and feminine. As feminism, ecofeminism insists that historical and interconnected twin exploitations of women (and other oppressed peoples) and nature be included in environmental problems; as an ecological feminism, ecofeminism insist upon the inclusion of appropriate insights and scientific ecology [3]. Ecofeminism believes that women understand and love nature instinctually, and oppose male oppression of women and aggression against nature under patriarchy. Ecofeminism calls for opposition, believes that the liberation of women and liberation are naturally inseparable. It mainly opposes mechanism natural view, insists on decentralization, actively promotes the ethical values of love, care and justice, and pursues harmonious coexistence. Mechanism natural view is based on Newtonian mechanics and is also the core idea of modern science. It takes the mechanical view of nature as the main point of study. It advocates the theoretical point of view of duality between man and nature, and believes that human beings are the only subject of nature. All other things in the world are just tools that should be controlled, transformed and used by humans. Affected by the viewpoint of mechanism, in the period of industrial civilization, human beings used advanced technology to exploit nature without restriction, which is an immoral behavior made by humans towards nature, leading to extreme opposition between humans and nature. Ecofeminism emphasizes that humans and nature should live in harmony to maintain ecological balance and sustainable development. Under the rule of androcentrism, men's oppression and enslavement of women are in same as nature's rule by humans. The domination has also reached its peak in the mechanical material view. Ecofeminists propose that human beings are equal to nature, conform to nature, respect the laws of nature, and believe that natural resources and environmental resources are not inexhaustible. Therefore, to achieve sustainable development, it is necessary to fully respect the equally dominant position of nature and achieve an equal dialogue between man and nature. 


\subsection{Ecofeminism in "The Story of an Hour"}

The Story of an Hour with its unique narrative structure shows Madame Mallard's psychological and physical changes from sadness to joy, from joy to surprise, from shock to sadness, and grief to the end. Joy comes from freedom, and freedom is given by nature; sorrow is born from bondage, and bondage is given by patriarchal culture. The treatment of the delicate natural relationship between nature and women in the story, and the description of the natural awakening of women's independent consciousness reflect the author's ecofeminist view.

The Story of an Hour is exciting at the beginning, which paved the way for the following plot. Mrs. Mallard suffered with a heart attack. Her sister and her husband's friends informed her about Mr. Mallard's death. The woman was so helpless and unable to accept reality, but "wept at once, with sudden, wild abandonment, in her sister's arms." [4] This shows that she is straightforward and also reveals subtleties of their relationship. Grief after the storm passed, she walked into the room upstairs alone, not allowing anyone to follow. In the room, she immediately turned her attention out of the window: "She could see in the open square before her house the tops of trees that were all aquiver with the new spring life." [4] The delicious breath of rain in the air and countless sparrows twittered in the leaves awaken Mrs. Mallard's sense of independence and freedom. Nature becomes a symbol of her psychological activities and a catalyst for her growth and maturity. However, her awakening was not achieved all at once, but gradually completed step by step, because she had been affected by the patriarchal society every day. "Now there was a dull stare in her eyes, whose gaze was fixed away off yonder on one of those patches of blue sky. It was not a glance of reflection, but rather indicated a suspension of intelligent thought." [4] At this time, Mrs. Mallard was in an unconscious situation, listened to her inner guidance and natural call, and wanted to get rid of the shackles of the patriarchal system and slowly recognize what was going to her. Freedom and independence are gifts from nature, awakening her consciousness from all directions. When freedom and independence came, she could not believe it or accept it. However, freedom is so noble and precious, she finally gave up resistance, repeating the word in a low voice over and over again: "Freedom, freedom, freedom!" [4] Her eyes became strong and bright, her pulse accelerated and flowed rapidly. Mrs. Mallard drew strength and warmth from nature, just as women and nature share voices, she listens to the voice of nature.

Although the Story of an Hour did not describe the destruction and oppression of nature by industrial civilization with great fanfare, the rational thinking caused by the commercial culture at that time and the sense of freedom inspired by nature formed a sharp contrast and a metaphorical sequence of antagonism between civilization and nature: civilization's rejection of nature, rationality's repression of emotion, and men's control over women. The description of environmental details and the portrayal of the characters' psychological activities blend with each other, closely, and vividly and truly highlight the subtle relationship between women and nature.

\subsection{Ecofeminism's Impact on Environmental Law}

Since the 1980s, the United Nations has begun to use gender analysis as an analysis category and research field to analyze the different impacts of the United Nations and various countries' policies and laws on men and women, and try to find solutions to problems. The Action Plan adopted by the Fourth World Conference on Women in 1995 identified gender mainstreaming as a global strategy to advocate gender equality. In 1997, the UN Economic and Social Council adopted a decision on gender mainstreaming. Mainstreaming gender issues will analyze the impact of any plan and action at all levels in any field, including legislation, policy or project plans, on women and men.

Ecofeminism provides us with a new perspective on the resolution of ecological crisis and the liberation of women. In the past, research regarding laws are usually lacked the perspective of female, but now, with ecofeminism, social gender and law are combined to be studied, legal system based on gender analysis will be rejected. Ecofeminism connects the goals of female liberation and natural liberation from a new perspective. It tries to find a solution to the ecological crisis by criticizing the mechanistic view of nature and patriarchal culture, re-defending the value of women and nature, and establishing a new type of social-ecological relationship in which people and nature live in harmony.

As Haraway argues: admitted or not, politics and ethics ground struggles over knowledge projects in the exact, natural, social and human sciences. It is significant to believe that ecofeminism and ecosystem ecology are two complement objects that reinforce mutually so that they can contribute together to our conversation with the world.

From the perspective of value, law has evolved from the original "human center" to "ecological center" and from the original "male power center" to "gender equality". The value pursuit of law has also changed from the value of security in traditional society at the core, and the value of freedom in the development of modern society is the most important; and this history of value changes is also a history of further expansion of the scope of value subjects. It is a process of expanding from slave owners to slaves, and fathers to sons. Women who are under the eyes of the law, people of color, and people 
with intellectual disabilities have all become the value subject of the law, and even become the object of the law's conscious preference. Many of the super-legal values that originally belonged to "female care" have been transformed into the proper meaning of legal value with the expansion of the subject's scope and the deepening of value connotation.

\subsection{Suggestion}

Women's important role in environmental protection is not accidental, but is determined by the special connection between women and nature. Eco-feminism is a new way of thinking and attitude towards life. It advocates the harmonious relationship between nature and women, and supports the establishment of a harmonious relationship between both man and nature and among different genders. Ecofeminism promotes changes in the value of law, and the value of law will also shape the evolution of the inherent needs of ecological feminism. The values of eco-feminism began to belong to the influencing preference value system. When it is determined as a consensus value sequence in the form of legal value, it will inevitably shape the changes in human nature in society. As Rosemary Ruther wrote in 1975 in her book, New Women/New Earth: women must see that there can be no liberation for them and no solution to the ecological crisis within a society whose fundamental model of relationships continues to be one of domination. Even though women and ecology movement are highly and inextricably intertwined, and even though acknowledging female and nature's dominance is of crucial importance to feminism, or environmentalism, in this paper, none of this convey any aspects that the principle of ecology has to be feminist. Future work should also include criticism of ecofeminism, since everything has two sides.

\section{CONCLUSION}

Ecological feminism attempts to unite the female and ecological movements together, claiming about the crucial role of feminism to environmentalism. The close connection between ecology and women has become a brand-new theory: the ecological crisis is caused by men's seizure of social rights, which is similar to women's long-term male oppression. Put forward a new concept of the existence and connection between women and natural life, it is believed that the form of the earth nurturing all things and the mother nurturing human life is the same. Therefore, women are closer to nature and are fitter to consider and comprehend the relationship between man and nature. However, this paper is not arguing that ecology must be view in feminism perspective, or that feminists must have ecologist's view. Instead, intersection between ecofeminist and environment and direction of future bridge-building between the two are identified. To keep developing these claims, much more studies would be needed than is provided in this paper.

\section{ACKNOWLEDGMENT}

I would like to than my professor and teachers. Without their support, this project would never have been completed. Also, I would like to thank my friends for their supports and inspiration.

\section{REFERENCES}

[1] Brisson, Sami, "Women's Connectedness to Nature: An Ecofeminist Exploration" (2017). Regis College Honors Theses. 1.

http://epublications.regis.edu/rc_etd/1

[2] GATES, BARBARA T. "A Root of Ecofeminism: Ecofeminism." Interdisciplinary Studies in Literature and Environment, vol. 3, no. 1, 1996, pp. 7-16. JSTOR, www.jstor.org/stable/44085413. Accessed 3 Sept. 2020.

[3] Warren, Karen J., and Jim Cheney. Ecological Feminism and Ecosystem Ecology. Hypatia, vol. 6, no. 1, 1991, pp. 179-197. JSTOR. Accessed 4 Sept. 2020.

[4] Kate Chopin (1894) The Story of an Hour

[5] Qianyan Chen. "Feminist Ecological View and its Enlightenment to the construction of ecological civilization in China" (2017). Bo Hai University.

[6] Ji Yan. "Feminist Perspectives on Women's Environment in the Perspective of Ecological Feminism". Huaibei Vocational and Technical College. 